資源と素材 (Shigen-to-Sozai)

Vol.116 p. $321-328(2000)$

$\operatorname{ccccce}$ 論文

\section{二酸化炭素ハイドレートを利用した \\ メタンハイドレート開発システムの提案*}

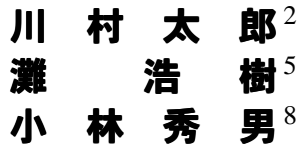

砢 井 ${ }^{{ }^{3}}{ }^{3}$
清 野 文 雄 $^{6}$
大 賀光 太 郎 $^{9}$

\title{
The Proposal of Methane Hydrate Development System using Carbon Dioxide Hydrate
}

by Hironori HANEDA ${ }^{1}$, Taro KAWAMURA ${ }^{2}$, Takeshi KOMAI ${ }^{3}$, Yoshitaka YAMAMOTO $^{3}$, Hiroki NADA $^{3}$, Fumio KIYONO ${ }^{3}$, Masayoshi TAKAHASHI ${ }^{3}$, Hideo KOBAYASHI ${ }^{3}$ and Kotaro OHGA ${ }^{2}$

1. National Institute for Resources and Environment, Shiroishi-ku, Hokkaido 003-0029

2. Graduate School of Engineering, Hokkaido University, Kita-ku, Sapporo 060-8628

3. National Institute for Resources and Environment, Onogawa, Tsukuba, 305-8569

As for the development of methane hydrate that exists under bottom of the sea, the safety measures are most important. The methane hydrate development system using artificial block and prop system was proposed to prevent the landslide and the sudden fall. Artificial block system is a method of improving strength of the sediment by injecting carbon dioxide into the sediment.

It was assumed to form carbon dioxide hydrate in the bottom of the sea stratum to achieve this purpose, and so we examined the properties of formation / dissociation, and the influence of the particle. The results obtained are as follows;

(1) The formation condition approaches the estimated equilibrium value by mixing the particle, and the level of the shift depends on the correlation of the heat conductivity of the particle and water. It can be suggested that carbon dioxide hydrate be formed easily at the case without the stratum particle when the carbon dioxide bubble rises as a result within the space of the particle in the sediment. It is considered that the dissociation condition of carbon dioxide hydrate almost agrees to the estimated equilibrium value in any case, and is not influenced by the presence of the stratum particle.

(2) It has been understood that the supercooling phenomenon be comes smaller with increasing the particle diameter, and that the particle diameter has close relation to the formation condition of carbon dioxide hydrate. This shows that the formation condition changes according to the particle diameter of the sediment.

(3) The initial formation rate varies from the range of 0.2 to $0.6 \mathrm{ml} /(\mathrm{min} \cdot \mathrm{g})$, and the dissociation rate varies from 1 to $1.5 \mathrm{ml} /(\mathrm{min} \cdot \mathrm{g})$ in case of carbon dioxide hydrate. The rates increase with the presence of the particle, and also increase with the particle diameter.

We will continue to achieve the methane hydrate development system by the experiment that uses similar particles to the strata of the sea sediment in the future.

KEY WORDS : Methane, Carbon Dioxide, Hydrate, Artificial Block System, Landslide Prevention

\section{1. 緒言}

ガスハイドレートとは , 低温高圧の条件においてガスと水が結 合して水状の固体結晶を形成したものである。メタンハイドレー

\footnotetext{
* 1999 年 10 月 1 日受付 11 月 10 日受理 資源環境技術総合研究所第 16 回研 究講演会において一部発表（1999 年 7 月 2 日）

1. 正会員 資源環境技術総合研究所北海道センター 主任研究官

2. 学生会員 北海道大学大学院生 工学研究科環境資源工学専攻

3. 正会員 工博 資源環境技術総合研究所 安全工学部 室長

4. 正会員 工博 資源環境技術総合研究所エネルギー資源部 主任研究官

5. 理博 資源環境技術総合研究所地殻工学部 研究員
}

卜は低温高圧の条件下で安定な水分子とメタン分子の包接化合 物 (クラスレート ) である。この状態では, 容積倍率が 172 のメ タンを含んでおり，これがメタンハイドレート貯留層を形成して いる( 佐藤ら，1996)。

6. 正会員 工博 資源環境技術総合研究所地殸工学部 主任研究官

7. 正会員 資源環境技術総合研究所安全工学部 主任研究官

8. 正会員 資源環境技術総合研究所地款工学部 室長

9. 正会員 工博 北海道大学大学院工学研究科環境資源工学専攻

[著者連絡先] FAX 011-864-3469 (資環研・羽田)

キーワード : メタン, 二酸化炭素, ハイドレート, 人工天盤, 地すべり防止 
メタンハイドレートは海底下および永久凍土の下に存在か確認 されており，海底下の主な分布はこれまでの調査活動により，環 太平洋の沈み込み帯, 太西洋の大陸斜面等に広がっている。日本 周辺では, 南海トラフ, 日高沖, 奥尻海嶺, オホーツク海等にメ タンハイドレートの存在が推定されている。永久凍土下のハイド レートは, シベリア , カナダ , アラスカ等に存在している (Sloan , 1998a)

光の資源量は世界の海域でハイドレートは $2.91 \times 10^{14} \mathrm{~m}^{3}$, フ リーガスは $1.13 \times 10^{14} \mathrm{~m}^{3}$, 日本の資源量は八イドレートが $4.7 \times$ $10^{12} \mathrm{~m}^{3}$, フリーガスが $2.7 \times 10^{12} \mathrm{~m}^{3}$ と推定され，この日本の資源 量は天然ガス国内消費量の 100 年分に相当するといわれている ( 佐藤ら，1996)。

以上のことから近年, メタンハイドレートは将来の有望な天然 ガス資源として, また, クリーンエネルギーとして注目を集めて いる。メタンハイドレートの開発手法は, 後述するように従来の 地下資源 (石炭, 石油, 天然ガス等) 開発とは大きな違いがある。 石炭は坑道を掘削して固体を採掘し, 石油, 天然ガスは井戶から 液体またはガスを, 兴のままの形態で地表へ搬出する採掘方法で あるが, メタンハイドレートは海底下に固体で存在しており, 光 のままの形態で採掘することは困難である。メタンハイドレート を原位置で固体からガスと液体へ相変化させ , 分解ガスだけを搬 出する採掘方法をとる必要がある。メタンハイドレートの開発に おいては, 固体から気体への分解を制御し, 必要な生産速度でガ ス採取が可能な革新的な技術を確立することが重要である。

メタンハイドレートの分解は吸熱反応なので, 分解速度制御に は, メタンハイドレート鉱床の圧力分布や鉱床周辺からの熱供給 等が大きく影響するため, 分解特性を定量的に把握することが必 要である。また , 分解したメタンガスや水が地層内をどのように 流動して生産井に集積するか, 分解ガスが抜けて水が残り不安定 となる地層の安定をどのように回復するか等も開発実現に向けて の重要な研究課題である。产の他, 坑井掘削の過程では, ガス八 イドレートの分解を抑制し坑井を安定に維持することが必要であ ること, 地層内や坑井・輸送パイプ内における分解ガスの再ハイ ドレート化を防止することも必要である。

これらの未解決の問題に共通するのは, ガスハイドレート固有 の特性, すなわち環境条件によって相変化することであり，筆者 等は, この特異性を明らかにすることがメタンハイドレート開発 の基礎・基盤となると考えている。

本論文では, メタンハイドレート開発システムの提案と, 弚れ を実現するために筆者等が行っている研究の報告を行う。

2. 海底メタンハイドレートの賦存形態と 開発における安全対策

2· 1 メタンハイドレート 鉱床開発における安全対策

海底下のメタンハイドレートは海底から比較的浅く, 間隙率の 大きい地層中に存在し, また, メタンガス採取後に水が残留する ことから，地層の安定をどのように維持するかが大きな問題とな る。地層の安定が崩れると地盤崩落や, これに起因する地すべり の発生する危険があり, また, 海底環境にも悪影響を与える。

海底地すべりについては ,Field. M. E. et al.(1993)やPeter Popenoe, E. A. et al.(1993) らが地すべりとガスハイドレートの関係を調査し た。产の結果, 大陸棚に沿った地すべりの原因の要素には大きな 地震, 地殻变動, 川から流れ込む大量の堆積物等とメタンハイド レートの関係を指摘している。堆積物層については, 砂質が粘土 質より地すべりを発生しやすいことを示した。Henriet, J. P. et al.(1999) は, メタンハイドレートの分解が地すべりの大きな要因
であることを言及した。

これらのことから, 地すべりは, 一つの要因というよりはむし ろ複数の要因によって引き起こされる可能性が高いといえるが， 地すべりの発生にメタンハイドレートが関係していることは否定 できない。

メタンハイドレートの上部にある堆積層には Peter Popenoe, E. A. et al.(1993) が述べているように砂質の軟弱層が多く，ハイド レートを開発し支持が無くなるとさらなる軟弱化が進むことが予 想される。軟弱な地層で地すべりが発生すると, 海水の流動に促 されてメタンハイドレートが急速に分解し, 海上に大量に放出す る危険がある。メタンガスが大量に海上に放出されると，海上の 掘削・生産設備または人命に多大な損害を与えることが懸念され る。特にメタンガスは 5 〜 15 vol \% で爆発する危険性を有してい る。

このような直接的な災害の他にも, 分解ガスの大量放出によっ てメタンハイドレート採掘の坑口の気密性が維持されなくなり， メタンガスが海中に流失し, 海水への影響, または大気中まで放 出されるといった地球環境への悪影響を考慮する必要がある。ま た, メタンハイドレートの分解により, 上部の堆積層が崩落し, 海底環境が乱されること, さらに, 規模が大きければ津波を発生 させる懸念もある。

以上のことから , メタンハイドレート採取に際して, 地すべり および海底地盤崩落等の災害を防止するため, 地層安定維持を図 るための対策を十分に講じる必要がある。

\section{$2 \cdot 2$ 海底地層の軟弱化防止策}

一般に, 土木工事における軟弱地盤の固化安定化には, グラウ チング薬液等の注入工法が用いられる。しかしながら, 水深数百 $\mathrm{m}$ 以深の海底地層に対し, 軟弱化防止対策が施された例は見あた らない。石油, 天然ガス開発の坑井掘削の場合には, 海底下の安 定した地層までケーシングを降ろし, セメントで固定し, 海底面 から $1,000 \sim 2,000 \mathrm{~m}$ 以上深い貯留層を開発対象とする。したがっ て, 海底下数百 $\mathrm{m}$ の比較的軟弱な地層は開発の対象とはなってい ない。しかしながら, 水深 $1,000 \mathrm{~m}$ あるいは $2,000 \mathrm{~m}$ の海底下のメ タンハイドレートは海底下 $300 \sim 500 \mathrm{~m}$ 程度が安定領域となって おり，この領域は間隙率が $30 \sim 50 \%$ 程度の軟弱層である。メタ ンハイドレート開発に際して, 地層安定化対策が不可欠である。

ガスハイドレートは包接するガスの種類により相平衡条件が異 なることが知られている。筆者等の室内実験においても，二酸化 炭素ハイドレートはメタンハイドレートより容易に生成し, 逆に 分解しにくいことを確認している。陸域のメタンハイドレート層 の上にキャップロックとしての役目を果たす永久凍土が広がって いることにヒントを得て, 海底地層中のメタンハイドレート層の 上位に二酸化炭素ハイドレートの天盤を設置できるのではないか とのアイデアが生まれた。

二酸化炭素ハイドレートを用いる理由はメタンハイドレートよ り安定していること, 温暖化ガスの処理, コストが安いことが挙 げられる。

筆者らが提案するように, 二酸化炭素を海底地層の軟弱化防止 に使用できれば新たな処理技術等を用意する必要はなく，地球環 境問題とエネルギー問題が同時に解決されることになる。

\section{3. 海底地層中のメタンハイドレート 開発システムの提案}

\section{3・1 人工天盤および人工支柱による採掘}

二酸化炭素ハイドレートの研究は, 大垣ら (1996) が二酸化炭素 ハイドレートの生成熱を熱供給剂として利用しながらメタンハイ ドレートを生産するシナリオを提案している。二酸化炭素混合ガ 
スのハイドレートの研究は John, V. T et al.(1985)や Ripmeester, J. A et al.(1998) が熱力学的な研究を行っている。また , 二酸化炭素の 直接海洋隔離については,Saito, T. et. al(1999) が二酸化炭素を直接 海水中に隔離するシステムを提案した。Brewer, P. G. (1999) は 2025 年に $1 \mathrm{Gt} / \mathrm{y}, 2050$ 年には $4 \mathrm{Gt} / \mathrm{y}$ の二酸化炭素を水深 5,000 ～6,000 $\mathrm{m}$ の海中にバブリングまたはハイドレート化して隔離する計画を 提案している。

このように二酸化炭素ハイドレートや二酸化炭素の海洋隔離の 研究は, 基礎的なものを中心として実際の海洋での実験が始まっ たばかりである。

著者らが提案するメタンハイドレート開発システムは次の $2 つ$ の新しいアイデアを含むものである。1 つ目はメタンハイドレー 卜層上部の地層に二酸化炭素を注入し, 地層内間隙に二酸化炭素 ハイドレートを成長させ人工天盤を構筑し，地層の安定化を図る。 2つ目はメタンハイドレート層に海水を流動接触させ ハイドレー 卜の分解制御を行いながらメタンガス採取を行う。すなわち，メ タンハイドレートの採掘跡に二酸化炭素を注入し, ハイドレート 化により地層安定の支柱の役目を果たすとともに, 二酸化炭素と メタンの置換によりさらなるメタンガスの採取を行う。

筆者らが提案するメタンハイドレートの採掘概念図を Fig. 1 に 示す。採掘の手順は研究成果を含めながら以下に示す。

3.1· 1 メタンハイドレート採掘範囲に二酸化炭素ハイドレー トによる人工天盤の構築 メタンハイドレート上部にある堆積 層に Fig. 1 に示す二酸化炭素注入坑井 1,2 , ( 複数本) を通して二 酸化炭素を注入し, 堆積層の隙間に二酸化炭素ハイドレートを成 長させ軟弱層の安定化を図る。生産坑井を中心に同心円状または 格子状に作業を進めればメタンハイドレート採掘範囲全体に人工 天盤が形成される。地層の間隙率は駒井・青木 (1996) によると砂 質層で $30 \%$ 程度であり，これらを基に地層を模擬した粒子中の 二酸化炭素ハイドレートの生成・分解について検討している。光 の結果は，4．で詳細に述べる。

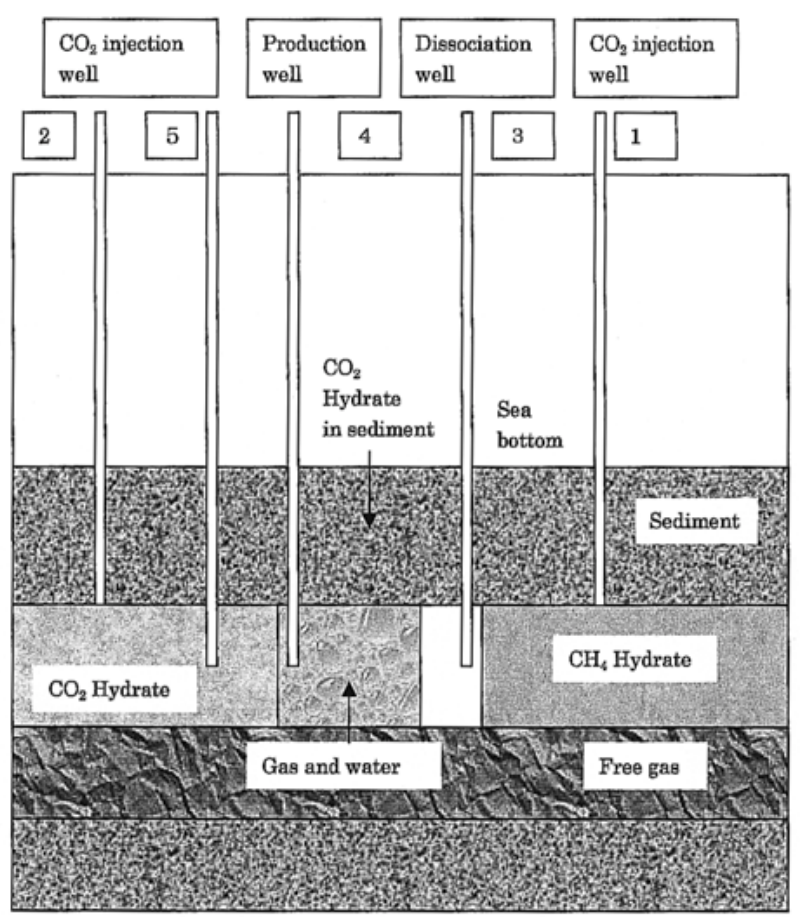

Fig.1 Methane hydrate extraction concept based on the artificially block method using Carbon Dioxide gas hydrate.
3· $1 \cdot 2$ 海水注入によるメタンハイドレートの分解 分解 坑井 3 から上層海水を注入してメタンハイドレート層の温度を上 昇させメタンハイドレートを分解させる。分解したメタンガスは 生産坑井 4 から回収する。Fig. 2 に示す各ガスハイドレートの相 平衡図から, メタンおよび二酸化炭素ハイドレートは相平衡曲線 より低温高圧側の領域で安定して存在し, 高温低圧側の領域では 分離ガスと水あるいは水が共存する。二酸化炭素ハイドレートは メタンガスハイドレートと較べてより低い圧力, より高い温度で 安定して存在する。したがって, 採掘の過程でメタンハイドレー 卜は分解するが人工天盤は光のまま二酸化炭素ハイドレートでと どまる条件を維持することにより，二酸化炭素ハイドレートの人 工天盤を残してメタンハイドレートの採取が可能となる。

3. 1· 3 二酸化炭素ハイドレートによる支柱の構築 メタ ンガスを生産した間隙へ注入坑井 5 より二酸化炭素を注入し，二 酸化炭素ハイドレートを生成させ, 人工支柱を構筑し, 人工天盤 の維持を図る。同時に分解したメタンガスを生産坑井 4 から回収 する。なお, 各坑井は別々の坑井ではなく作業過程により二酸化 炭素の注入, 海水の注入, 生産の 3 つ目的で用いる。温度, 圧 力条件を制御した環境下で二酸化炭素ガス注入によりメタンハイ ドレート中のメタンが置換されることを駒井ら（1999）や成田 (1999) が実験により明らかにしている。駒井ら (1999) の報告によ ると, 圧力 $3.5 \mathrm{MPa}$, 温度 $4 \stackrel{\mathrm{C}}{\mathrm{C}}$ 前後の条件下でメタンハイドレー ト中のゲスト分子の一部がメタンから二酸化炭素に置換されるこ とを示した。これは, 気体または液体を経由しないで, 固体の状 態を維持しながら，直接的に置換できることを示唆する。すなわ ち, Fig. 1 に示すようなコンセプトで, 温度・圧力の制御により メタンを優先的に回収すると同時に, 二酸化炭素ハイドレートを 生成させて, 安定な地層を形成できる可能性を示している。また， 清野・高橋 (1999) はメタンガスの気泡径を測定し，メタンで飽和 された溶液とメタンの気泡による気液二相流が貯留層内または楊 鉱管内を流動する場合のメタンハイドレートの挙動予測を明らか にしつつある。

3・1・4 必要なメタン生産速度を得るためのメタンおよびニ 酸化炭素ハイドレートの生成・分解の制御 メタンハイドレー トからメタンガスを生産する過程では前記の海水の注入時に炎の 温度を制御する方法, 二酸化炭素ハイドレートの生成速度を利用 した制御方法の他, 海水への添加剂を用いた制御方法などが考え

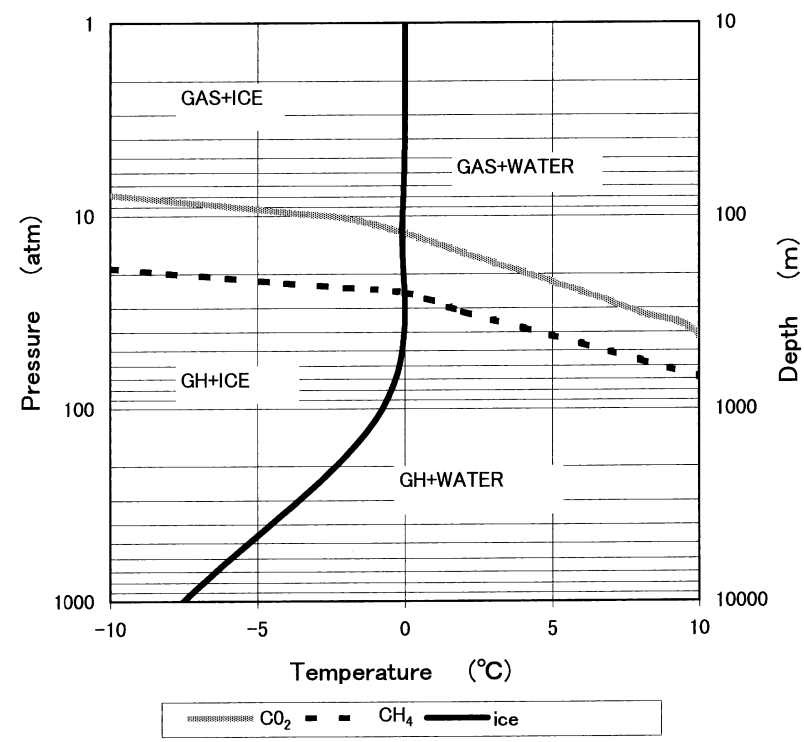

Fig.2 Phase diagrms of gas hydrates $\mathrm{CH}_{4}, \mathrm{CO}_{2}$ and ice (after Sloan 1998). 
られる。灘 (1997) はメタンハイドレートに関する分子動力学シ ミュレーションを行い, ハイドレートの核生成機構についてメタ ン分子周囲の水分子の籠型構造は水分子の集団運動によって形成 されることを示した。また产の際, 水分子の回転運動が籠型構造 の形成速度 , すなわちメタンハイドレートの生成速度を律速して いることを見出した。山本ら（1998）は液体クラスタービーム質量 分析装置を用い, 水溶液の構造解析を行った。メタノールがハイ ドレートのインヒビターとして働く機構として , 水クラスターに 対して，じゃまな存在である水一メタノール分子対が形成される ことを明らかにした。すなわち，水分子同士の水素結合によるネッ トワークの発達を阻害し, ハイドレートの部分構造を生成しにく くすることが重要である。この分子対は高圧ほど形成されやすく， ガスハイドレート生成に対するメタノールのインヒビターとして の効果は，高圧力下で顕著であることを示した。奥井ら (1996) は 水相に水溶性有機物が添加剂として共存する場合について, メタ ンで加圧して生成するハイドレートの生成・分解の平衡線の測定 と, 生成速度の測定を行った。光の結果, メタンを安定にハイド レート化する添加剂の構造的な傾向，およびメタン吸収速度の添 加剂による違いが示され，メタンを含むハイドレート相の平衡論 的および速度論的な特性が，水相への添加剂により制御できる可 能性を示した。

このように最近では分解促進剂を用いた制御の研究も急速に進 みつつあり，採掘されるメタンハイドレートの生成・分解速度の 制御, および注入する二酸化炭素ハイドレートの生成速度の制御 に利用できる技術に発展する方向にある。

\section{2 メタンハイドレート開発実現への課題}

提案したメタンハイドレート開発システムを実現するために今 後解決しなければならない主な課題として, 以下の 4 点が挙げら れる。

1） ガスハイドレートを含む海底地層中の海水, ガス等の流動 特性の把握

・堆積層間隙中の二酸化炭素の浸透特性

・ 海水中への二酸化炭素の溶解特性

2）海底地層中でのガスハイドレートの生成・分解条件の把握 - 堆積層粒度と二酸化炭素ハイドレート生成・分解条件

・堆積層物質の熱伝導率と二酸化炭素ハイドレート生成・
分解条件

3）混合ガスハイドレートの生成・分解条件の解明

・ 二酸化炭素濃度とハイドレート生成·分解条件

・メタンハイドレートと二酸化炭素の置換特性

・ 海底下で分解したメタンガスの海水中での流動挙動

・堆積層中でのメタンー二酸化炭素混合ハイドレートの相 平衡

4） ガスハイドレートの大量 ·高速生成 ·分解の方法検討

· 二酸化炭素ハイドレートの急速大量生成技術の開発

・ ガスハイドレートの海水温度差による分解挙動の解明

これらの問題点を踏まえ, 本研究では2)に示す課題について模 擬地層を用いて検討した。以下, 谷の結果について報告する。

4. 模擬地層中におけるガスハイドレート の生成·分解実験

4・ 1 実験装置および実験方法

ガスハイドレートの生成・分解挙動について粒子の熱的性質に ついて検討する大型実験装置と粒子径の差異を検討する小型の実 験装置を用いて検討した。大型実験装置は Fig. 3 に概略を示すよ うに, 高圧容器部, 恒温装置部, ガス制御部, データ計測部から 成っている。高圧容器本体は内径 $6 \mathrm{~cm}$, 高さ $100 \mathrm{~cm}$, 容積 2,800 $\mathrm{m} l$, 最高使用圧力 $4 \mathrm{MPa}$ のポリカーボネート製である。本体には 温度を制御するため外筒を設けており, 外部の冷却装置から冷媒 を循環している。高圧容器は上下のカバーで締め付けており, 上 カバーには温度センサ , ガス排出口を , 下カバーにはガス入口 , 水の入排出口を設けている。

ガスは二酸化炭素ボンベより流量計, 圧力制御器および高圧バ ルブを経て高圧容器に圧入する。ガス排出経路には圧力センサ， 高圧バルブおよび流量計を設けている。

高圧容器内部の圧力, 温度とガス経路の流量の各データは各セ ンサで計測し , パーソナルコンピュータに収録する。

実験の手順は次の通りである。まず, 高圧容器に純水 $(1,000 \mathrm{~m} l)$ または, 堆積地層を模擬する粒子と純水を入れ, 二酸化炭素ガス を所定の圧力まで圧入する。次に容器内の温度を約 $0.1 \mathrm{~K} / \mathrm{min}$ の 一定速度で $273 \mathrm{~K}$ 付近まで低下させる。低下させた温度を維持し， または, 徐々に温度を低下させて二酸化炭素ハイドレートを生成

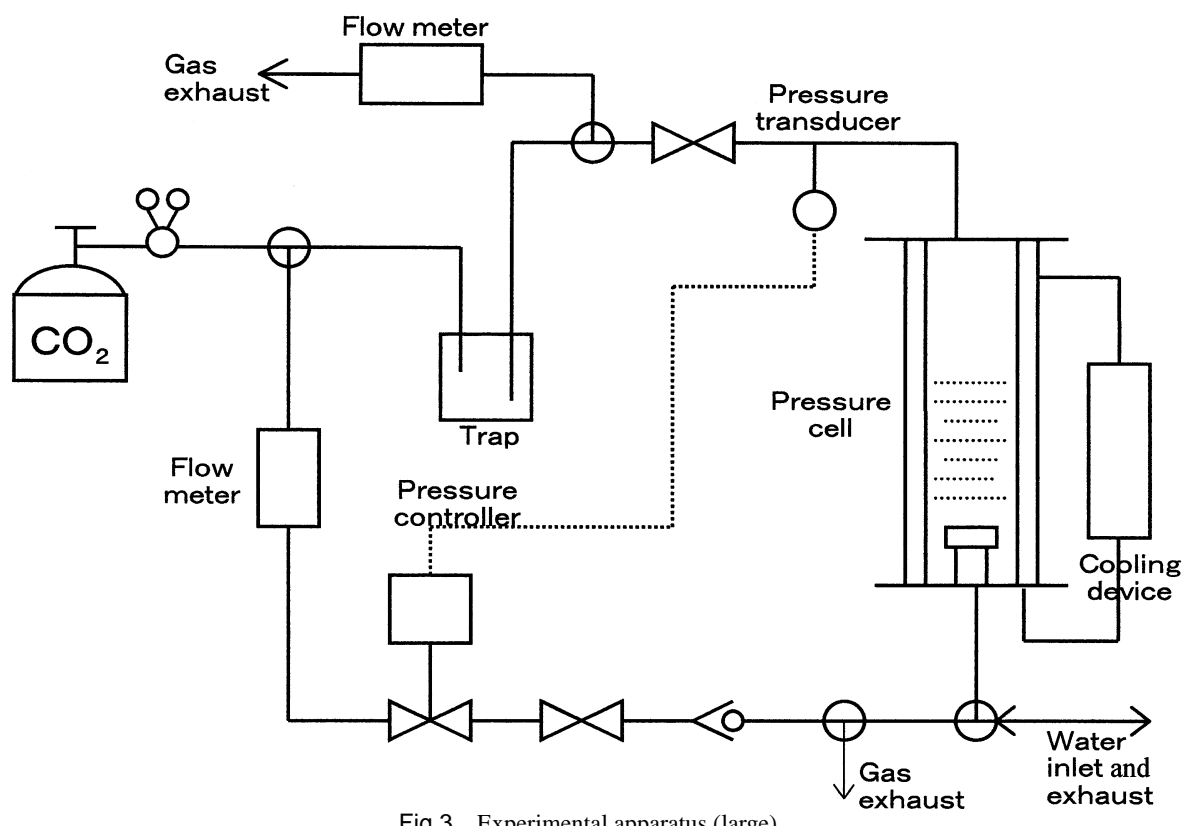

Fig.3 Experimental apparatus (large) 
させ，生成したときの温度を保持したまま成長させる。炎の後， 高圧容器内の温度を上昇させ二酸化炭素ハイドレートを分解させ る。なお,ハイドレートが生成するまで二酸化炭素を $200 \mathrm{ml} / \mathrm{min}$ でバブリングをした。

この間, 目視およびビデオ撮影によって高圧容器内の状態変化 を観察するとともに, ガス排出経路に設置した圧力センサで圧力 変化を, 高圧容器内に設置した温度センサで気相, 液相およびハ イドレートの温度変化を測定する。

粒子にはガラスおよびナイロン粒子の 2 種類を用い, 直径はい ずれも $5 \mathrm{~mm}$ とした。粒子の材質を変えた理由は, 堆積物中，ま た多孔質体の性質の違い，例えば，熱伝導率等がハイドレート生 成・分解に及ぼす影響を調べるためである。

実験は毎回純水を交換し, 高圧容器に入れる粒子の種類および ガスの圧力を変えて繰り返し行う。

小型実験装置は Fig. 4 に概略を示すように高圧容器部，ガス制 御部, データ計測部から成っている。高圧容器本体は使用最高圧 力 $10 \mathrm{MPa}$, 内容積 $390 \mathrm{ml}$ のステンレス製である。本体には温度 制御用のジャケットを設けており, 外部の冷却装置から冷媒を循 環して本体内部の温度を制御している。本体側面には容器内部の 観察用覗き空を設けている。高圧容器カバーには回転軸, 温度セ ンサ, ガス入排出口を設けている。回転軸は容器内部の攪拌羽根 を外部の電動機により回転させている。

ガスはボンベから高圧容器に送入する。この経路には圧力セン サ, 圧力制御器, 安全弁, 流量計, 高圧バルブを設けている。ガ ス排出経路にはガス採取口, 流量計, 高圧バルブを設けている。

高圧容器内部の圧力, 温度とガス経路の流量の各データは各セ ンサで計測し，パーソナルコンピュータに収録する。

実験は高圧容器に純水 $(50 \mathrm{~m} l)$ またはガラスビーズ $(50 \mathrm{~m} l)$ と光 の空隙に純水を満たし, 内部空気を置換する。置換の確認は Fig. 4 のガス採取口からガスを採取しガスクロマトグラフィで分析す ることにより行う。置換が確認された後, 二酸化炭素を任意の圧

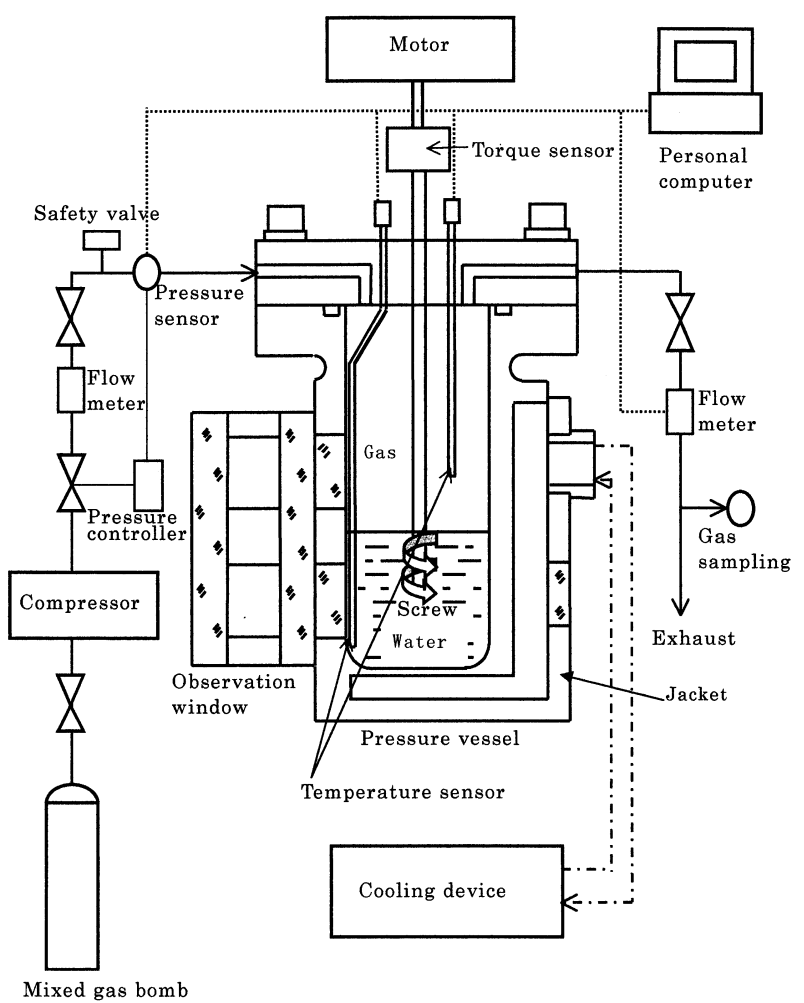

Fig.4 Experimental apparatus (small).
力まで圧入する。次に攪拌装置で高圧容器内部の液相を $200 \mathrm{rpm}$ で靦拌しながら温度を約 $0.1 \mathrm{~K} / \mathrm{min}$ の一定速度で $273 \mathrm{~K}$ 付近まで 低下させる。低下させた温度を維持し, または, 徐々に温度を低 下させてガスハイドレートを生成させ , 生成した温度を保持した まま成長させる。产の後, 容器内の温度を上昇させ, ガスハイド レートを解離させる。

この間, 目視およびビデオ撮影によって高圧容器内の状態変化 を観察するとともにガス経路に設置した圧力センサで圧力変化 を, 高圧容器内に設置した温度センサで気相, 液相, ガスハイド レートの温度変化を測定する。

実験は毎回純水を交換し, 高圧容器に圧入するガスの圧力また は粒子の径を変えて繰り返し行う。実験に用いた粒子はガラス ビーズで, 光の直径は $5 \mathrm{~mm}, 0.8 \mathrm{~mm}, 0.2 \mathrm{~mm}$ である。

\section{2 実験結果および考察}

4. $2 \cdot 1$ 生成- 分解条件の測定 大型装置を用いた生成·分 解実験より得られた高圧容器内の圧力と液相中の温度変化の一例 を Fig. 5 に示す。初期条件として高圧容器内部の圧力を $2.5 \mathrm{MPa}$, 温度を $298 \mathrm{~K}$ に設定し, 約 30 分間放置した。光の後, 温度を一定 速度 $(0.1 \mathrm{~K} / \mathrm{min}) て ゙ 275 \mathrm{~K}$ 付近まで低下させた。誘導期間を経て 370 分頃に発熱現象が認められ (Fig. 5, T1), 同時に容器内気相の 圧力低下か認められた。

ガスハイドレートを成長させた後 , 1,530 分に容器内の温度を一 定速度 $\left(0.1{ }^{\circ} \mathrm{C} / \mathrm{min}\right)$ で上昇させたとき, 1,600 分頃に温度上昇速度 の低下現象 (Fig. 5, T2) と容器内の圧力上昇が認められた。これ らの観察から, ガスハイドレートの相変化に伴って液相の温度変 化が一時的に顕著に発生することが分かった。乥こで, 本稿では これらの温度の変化点をもって生成点 (Fig. $5, \mathrm{~T} 1$ ) および分解点 (Fig. 5，T2）とした。ハイドレート生成時に温度変化のピークが 2 つ認められるが, 最初のピーク $\mathrm{T} 1$ の生成熱により一時的に成長 が停止し，2つ目のピークは連続成長の開始点である。

$4 \cdot 2 \cdot 2$ 気一液相でのガスハイドレートの生成·分解条件

$4 \cdot 2 \cdot 1$ 項のようにして求めた純水と二酸化炭素によるハイド レートの生成 (○)・分解 (口) 点と, 直線で示した Sloan(1998b) による相平衡関係を Fig. 6 に示す。Fig. 6 においてハイドレート の分解点は, Sloan(1998b) が示した相平衡值とほぼ一致し, 加熱 現象は見られないが, 生成点は光れより低温高圧の条件側に移動 している。このように生成点が分解点より低温高圧側 (過冷却) と なることについては, Sloan(1998c) によると生成点は分解点の低 温高圧側のどの点で生成しても不思議ではない。弚れは最初の核 生成がどのタイミングで起こるかによるもので，この核生成の発 生条件は実験装置, 溶液の状態などで樣々に変化する。このこと

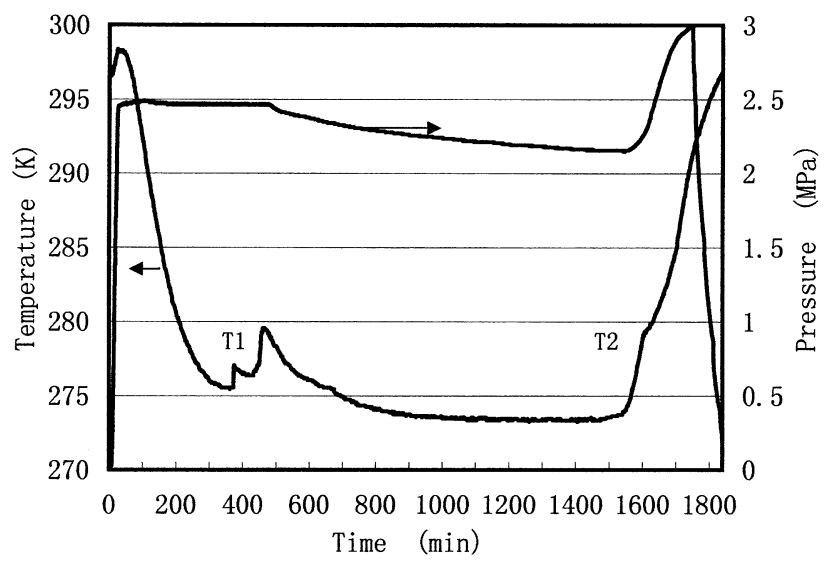

Fig.5 Tipical experimental results of $\mathrm{CO}_{2}$ hydrate formation and dissociation. 


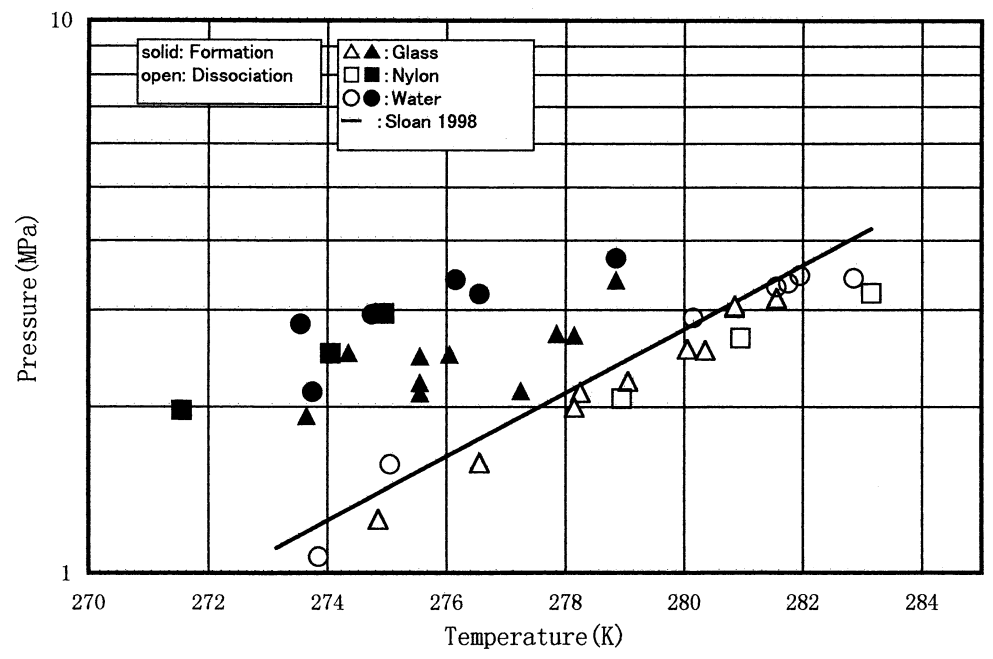

Fig.6 The relation between pressure and temperature for $\mathrm{CO}_{2}$ hydrate existing with several kind of beads.

は二酸化炭素ハイドレート生成時にも相転移による過冷却現象が 生じることを示している。

ハイドレートの成長過程は液相の界面で生成，成長するもの，

フィルター直上で生成し枝状に成長するもの, 二酸化炭素が液化

して液相が 2 層になる場合, など樣々な生成, 成長の樣相が観察 された。

これらのことから，原位置において二酸化炭素ハイドレートの 生成はS Sloan(1998b) が示した值よりも低温・高 圧側の条件になり，生成条件は不安定になりや すいことが分かる。

$4 \cdot 2 \cdot 3$ 固一液一気相でのガスハイドレー 卜の生成·分解実験 純水と二酸化炭素によ る各種粒子を用いたハイドレートの生成・分解 条件を Fig. 6 に示す。Fig. 6 によれば生成点は ガラス粒子を付加した場合（ $\boldsymbol{\Delta}$ ）には純水のみ の場合 (○)よりも高温低圧側に移動する傾向 を示し，ナイロン粒子（口）を付加した場合に は純水と同程度の值を示した。すなわち，ガラ ス粒子を付加した場合には , 純水のみの場合や ナイロン粒子を付加した場合より生成しやす いことが分かる。

実験で用いた粒子物質の熱伝導率 $\mathrm{K}(\mathrm{W} / \mathrm{m}$ ・ K) は , ガラスが 1.0 , ナイロンが 0.27 および水 が 0.56 である。付加する粒子の熱伝導率の值と 各生成点の関係を調べると，熱伝導率が水より 大きければ生成しやすい傾向を示す。一方，熱 伝導率が水より小さければ，ハイドレート生成 に際しての混合相中への熱移動量が水に支配 され, 水のみの場合と同じ傾向を示すことが分 かる。

分解条件はいずれの場合も Sloan(1998b) が示 した值とほぼ一致し，粒子の熱伝導率の影響あ るいは純水との差は見られない。

これらのことは, 原位置における堆積層の熱 伝導率により二酸化炭素ハイドレートの生成 条件か変わることを示している。

砂の熱伝導率は一般に $0.26 \sim 0.28(\mathrm{~W} / \mathrm{m} \cdot \mathrm{K})$ であり，水の熱伝導率より小さいので，気一液 相の場合と同じ生成条件になり，粘土質になれ
ばその值は $2.0(\mathrm{~W} / \mathrm{m} \cdot \mathrm{K})$ であり, 生成条件は Sloan (1998b)が示した值に近づき生成しやすくな ることか推測される。また, 分解条件は地層を構 成する粒子の影響を受けないことが推測される。

4・ $2 \cdot 4$ 純水を用いた生成・分解条件 (小型 実験）小型実験装置を用いた純水と二酸化炭 素からのハイドレートの生成・分解条件を Fig. 7 に示す。Fig. 7 において二酸化炭素ハイドレート の分解条件はSloan(1998b) が示した值とほぼ一致 するが, 生成条件は低温高圧側入移動している。

これらのことは前記の大型実験装置の結果と 同じである。

4. $2 \cdot 5$ 生成・分解条件に及ぼす粒径, 間隙 率の影響 ( 小型実験 ) 小型実験装置による結

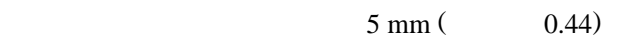
$0.8 \mathrm{~mm}$ ( 同 0.36),0.2 mm( 同 0.26)のガラス粒子に よるハイドレートの生成・分解条件を Fig. 8 に示 す。Fig. 8 において，ガラス粒子径が大きくなると生成しやすく， 径が小さいと低温高圧側へ移動し,生成し難くなることが分かる。 $0.2 \mathrm{~mm}$ の径ではほぼ純水の場合と同樣な値を示した。

分解条件についてはすべての場合において Sloan(1998b) が示し た相平衡関係とほぼ一致し, ガラス粒子径の影響を受けないこと が分かった。

これらのことは, 原位置地層中の粒子径により二酸化炭素ハイ

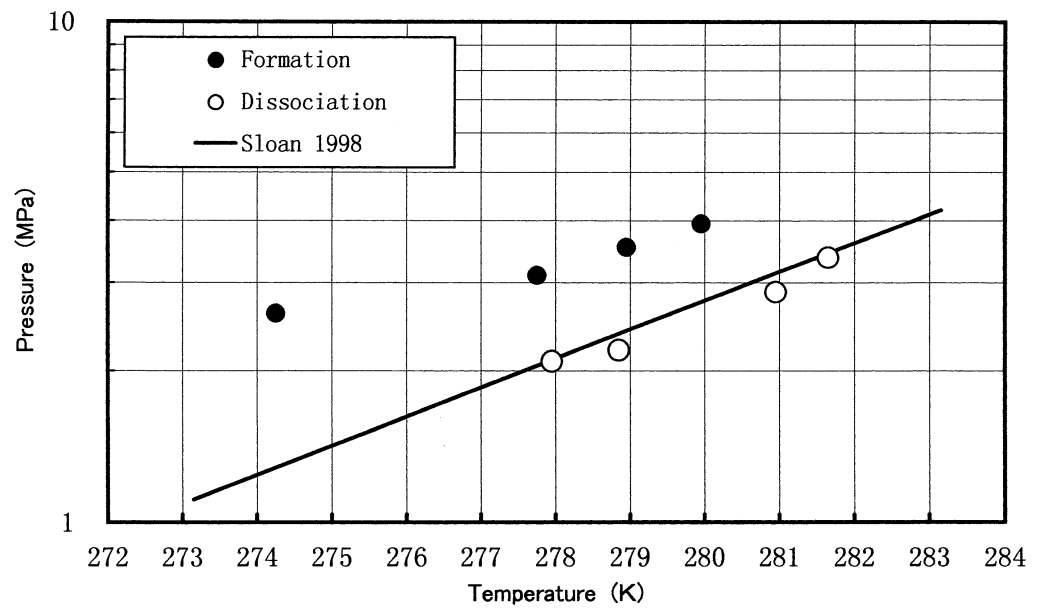

Fig.7 The relation between pressure and temperature at the formation and dissociation of $\mathrm{CO}_{2}$ hydrate

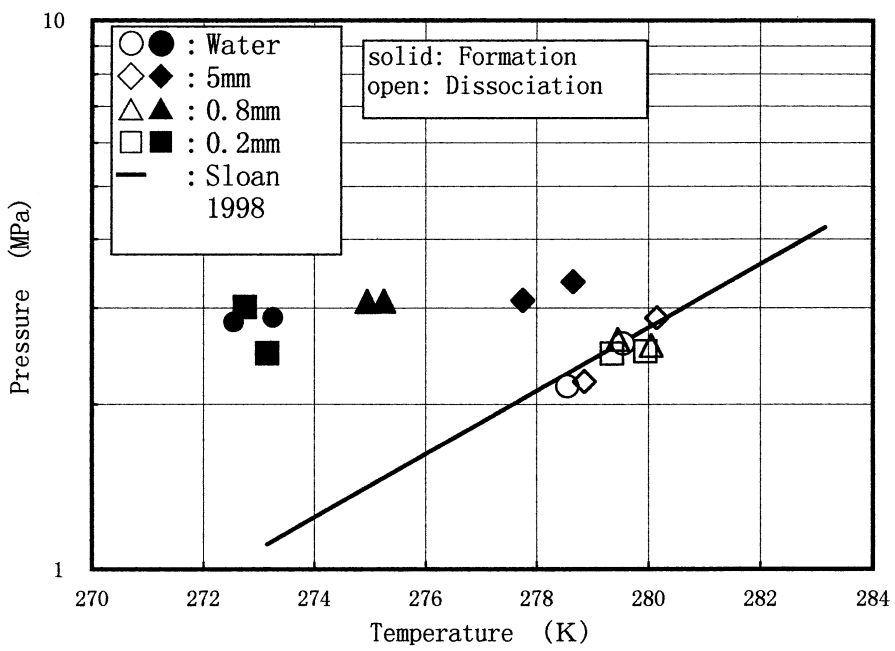

Fig.8 Influece of beads size on formation and dissociation of $\mathrm{CO}_{2}$ hydrates. 


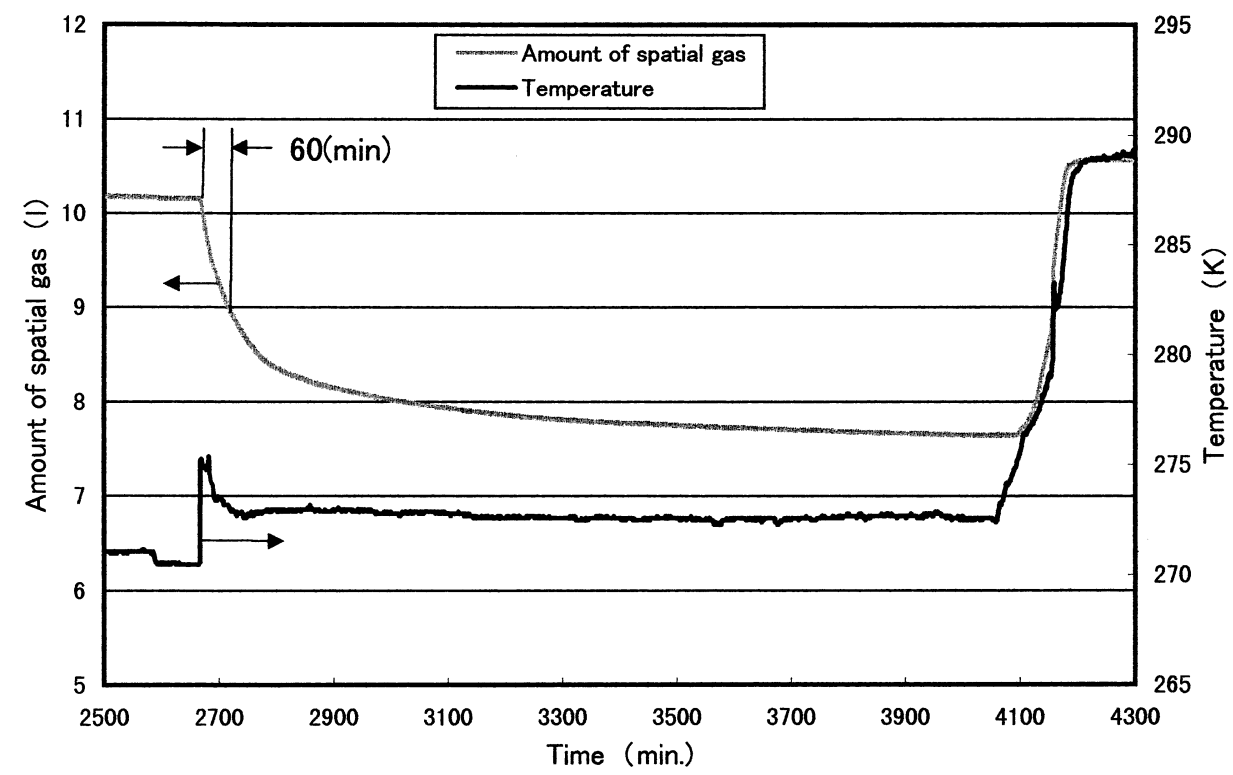

Fig.9 The curves of the amount of spatial gas and temperature obtained during in the $\mathrm{CO}_{2}$ hydrates formation and dissociation.

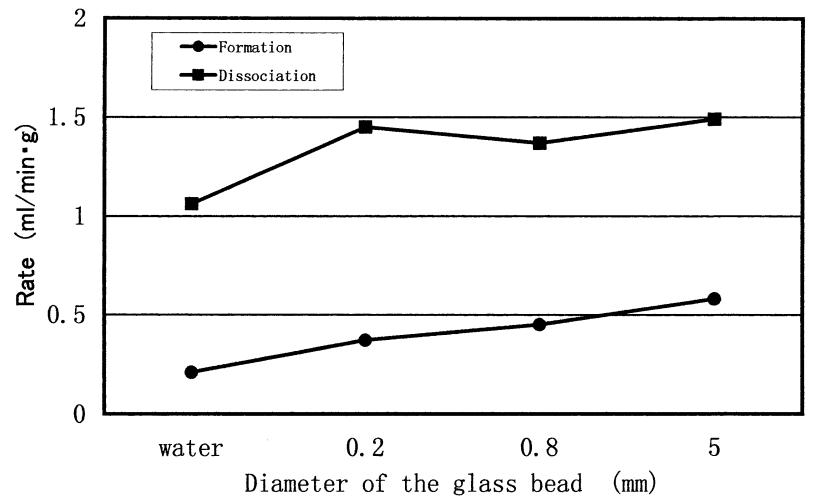

Fig.10 The formation and dissociation rates of $\mathrm{CO}_{2}$ hydrates existing with different size glass beads.

ドレートの生成条件が変化することを示唆している。一方 , 分解 条件は粒子径の影響を受けないことを示している。

$4 \cdot 2 \cdot 6$ 初期生成速度および分解速度 (小型実験 ) 二酸化 炭素ハイドレートが生成・分解する際の高圧容器内における空間 ガス量を高圧容器内の圧力, 温度変化より求めた。空間ガスと温 度の時間変化を Fig. 9 に示す。実験開始後 2,670 分頃における二 酸化炭素ハイドレート生成熱の発生と同時に, 高圧容器内の空間 ガス量は急速に減少している。また, 二酸化炭素ハイドレート分 解時における高圧容器内の空間ガス量は 4,110 分頃の分解点での 吸熱反応と同時に増加し, 温度の上昇に伴って増加している。な お，初期圧力は $3.5 \mathrm{MPa}$ の同一条件で実験を行った。

ハイドレート生成時にガス量がほぼ直線的に低下する部分 $(60$ 分間）を用いて初期生成速度を求め, また, 分解時の全体ガス量 から分解速度を求めた。关の結果を Fig. 10 に示す。Fig. 10 から， 純水だけの場合の初期生成速度は $0.2 \mathrm{ml} /(\mathrm{min} \cdot \mathrm{g})$ ( 水 $1 \mathrm{~g}$ 当たり 1 分間に取込むガス容量を標準状態に換算した值）程度であるが， ガラス粒子を混入すると $0.4 \sim 0.6 \mathrm{ml} /(\mathrm{min} \cdot \mathrm{g})$ 程度となり, ガラ ス粒子を混入すると, また, 兴の粒径を大きくすると初期生成速 度は上昇する傾向を示した。分解速度は純水だけの場合約 $1 \mathrm{ml}$ $(\mathrm{min} \cdot \mathrm{g})$ であり，粒子を混入すると $1.5 \mathrm{ml} /(\mathrm{min} \cdot \mathrm{g})$ 程度となり， 初期生成速度と同樣な傾向を示した。

このことから, 水中よりも堆積物中の方が二酸化炭素ハイド レートの生成速度が大きく, 兴の粒径が大きいほうが成長が速く
なることが推測される。

\section{5. 結言}

海底下に存在するメタンハイドレートは次世代のクリーンエネ ルギーとして注目を集めている。このメタンハイドレートの開発 には安全対策が最も重要であり, 特に地すべり, 堆積層の崩落を 原因とした大災害を防止するための技術開発が望まれる。

地すべり, 崩落を防ぐために人工天盤, 人工支柱を用いたメタ ンハイドレート開発システムを提案した。人工天盤は堆積層に二 酸化炭素を注入し, 堆積層の強度を高める方法である。人工支柱 はメタンハイドレートが分解した跡の間隙に二酸化炭素ハイド レートを生成させて, 堆積層の崩落を防ぐものである。

この目的を達成するため, 海底地層中に二酸化炭素ハイドレー 卜を生成することを想定し, 兴の生成・分解と粒子との関係につ いて検討した。得られた知見は以下の通りである。

（1）二酸化炭素ハイドレートの生成条件はS Sloan(1998b) が示し た相平衡関係より低温高圧側にあり, 過冷却の条件とすることが 必要である。粒子を混入することにより生成条件は相平衡值に近 づき, 弚の移動の程度は粒子と水の熱伝導率の相対的関係に依存 することが示された。この結果から，堆積層中の粒子の間隙を二 酸化炭素の気泡が上昇する場合には, 地層粒子が無い水中の場合 より二酸化炭素ハイドレートが生成しやすいことが推測される。 二酸化炭素ハイドレートの分解条件はいずれの場合も相平衡値と ほぼ一致し，地層を構成する粒子の影響を受けないと考えられる。

（2）混入した粒子径と二酸化炭素ハイドレートの生成条件の 関係については，粒子径を大きくするほど過冷却現象を受け難く， 生成しやすいことが分かった。これは, 堆積層の粒子径により生 成条件が変化することを示している。分解条件は, 堆積層の粒子 径の影響を受けないと考えられる。

（3）二酸化炭素ハイドレートの生成速度は $0.2 \sim 0.6 \mathrm{ml} /(\mathrm{min} \cdot \mathrm{g})$, 分解速度は $1 \sim 1.5 \mathrm{ml} /(\mathrm{min} \cdot \mathrm{g})$ 程度であり, 粒子を混入すると, また，光の粒径を大きくすると光れ光れの速度は大きくなった。 このことから，水中より堆積層の方が，また，粒子径が大きくな ると二酸化炭素ハイドレートの成長が早くなると推測される。

これらのことから, 二酸化炭素ハイドレートの安定性は海中お よび堆積層で同程度であり, 堆積層中では生成しやすく，产の速 度は海中より速くなる。よって, 二酸化炭素ハイドレートによる 
人工天盤 , 人工支柱の可能性は十分に考えられる。

このように，二酸化炭素ハイドレートの生成・分解に及ぼす粒 子の影響を実験的に示したが, 今後さらに海底堆積層に類似した 粒子を用い,研究を進めることにより，提案したメタンハイドレー 卜開発システムの実現に近づけたいと考える。光のためには，ガ スハイドレートを含む海底地層中の海水, ガス等の流動特性の把 握, 混合ガスハイドレートの生成・分解条件の解明, ガスハイド レートの大量・高速生成・分解の手法検討，等々を解明する必要 がある。これらは , 人工天盤を用いたメタンハイドレート開発シ ステムにおいて必要不可欠な知見であり，今後重点的に研究を進 める予定である。

\section{引用文 献}

Brewer. P. G. (1999) : Third International Conference Gas Hydrates, Manuscript No. 19 Field. M. E and Barber, J. H, Jr. (1993) : U. S. Geological Survey Bulletin, Vol. 2002, p. $151-$ 157
Henriet, J. P, et. al. (1999) : Third International Conference Gas Hydrates, Manuscript No. 42 John. V. T et. al. (1985) : AIChE. J, Vol. 31, p. 252-259. 清野文雄 (1999) : 資源・素材学会平成 11 年度春季大会講演要旨集, I, p. 41-42 駒井 武·青木一男 (1996): 資源・素材学会平成 8 年度春季大会講演要旨集, I, p. 29 駒井 武, 他 (1999)：Third International Conference Gas Hydrates, Manuscript No. 58 灘 浩樹 (1997) : 安全工学, Vol. 36, p. 451-456 成田英夫 (1999): 北海道応用地学合同研究会論文集, No. 10, p. 95-102 Ohgaki, K. et. al, (1996) : J. Chem. Eng. Jpn, Vol. 29, p. 478-483

奥井智治, 他 (1996): 月刊地球, Vol. 18, p. 690-694

Peter Popenoe, E, A. et. al. (1993) : U. S. Geological Survey Bulletin, Vol. 2002, p. 40-53 Ripmeester J. A. and Christopher I. Ratcliffe. (1998) : Energy Fuels. Vol. 12, p. 197-200 Saito, T. et. al. (1999) : Chemical Engineering Science, Vol. 54, p. 4945-4951 佐藤幹夫·前川竜男 · 奥田義久 (1996) : 地質学雑誌, 102(11), p. 959-971. Sloan. E. D, Jr. (1998a) : Clathrate Hydrates of National Gases, p. 20

Sloan. E. D. Jr. (1998b) : Clathrate Hydrates of National Gases. the values predicted by the program package.

Sloan. E. D. Jr. (1998c) : Clathrate Hydrates of National Gases. p. 75-76

Yamamoto, Y. Nagashima, K and Wakisaka, A (1998) : Atualdes de Fisico-Quimica Organica, Vol. 11 , p. $330-347$ 